\title{
Introduction
}

\section{Earthquake Music and the Politics of Conversion}

For it is not light that we need, but fire; it is not the gentle shower, but thunder. We need the storm, the whirlwind, and the earthquake.

-FREDERICK DOUGLASS

Pastor Graham waited for me at a table in the International Food Court in downtown Los Angeles. A week earlier, in the spring of 2007, I met the former gangbanger-turned-preacher at a Hip Hop Church L.A. Friday night service in Inglewood, where he delivered a powerful sermon on the nature and importance of compassion. His hair tightly braided in cornrows and his skin heavily inked with tattoos, Pastor Graham - at thirty years old - was one of a growing cadre of young black hip hop pastors and gospel rappers in Los Angeles. When he was not delivering the Word, he was rapping with members of Hood Ministries-a collective of gospel MCs and street disciples whose sound more closely resembled gangsta rap than gospel music. Over a slice of pizza, I asked him, "What do you call your music?" He contemplated while finishing his mouthful, then answered, "I don't like to call it Christian rap or gospel rap or even holy hip hop 'cause that sometimes scares people off." A few bites later, he proudly declared, "I call it earthquake music, because this music shakes our souls and moves the ground we walk on." Earthquake music.

Our conversation grew more intensely personal. I learned about his turbulent upbringing during the 1980 os and '9os at the height of L.A.'s gang wars and police raids: how an older gang member introduced him to using a gun on the streets of Compton, California, when he was just nine years old and how he ended up in jail at age seventeen. His hustling lifestyle brought him fast money, cars, and women, but he lost it all as quickly as he made it. After staring down the barrel of his own gun, a trigger pull from ending his life, he awoke to a new spiritual path. "To find a way through these streets, I had to look to the sky, but also dig deep," he uttered as he recalled this seismic shift in his life. His gaze dropped to the ground. "God kept 
me moving out here, but my heart is scarred from everything I've been throughall the tragedy around me. That's why we gotta make this earthquake music."

\section{SOUTHLAND ERUPTIONS}

Hip hop, since its fabled birth in another devastated city-the Bronx, New Yorkhas been both a disruptive and transformative force. In the 1970s, amidst postindustrial neglect, white flight, extreme poverty, street gang wars, and the looting and arson associated with ongoing New York City blackouts, black and brown youth turned violent and competitive energies into artistic expression. DJs created funky beats out of preexisting technologies and old records while MCs developed raw, rhythmic rhymes that voiced their daily lives and future aspirations. East Coast politicians and media sources typically "wrote off" or demonized this burgeoning youth arts culture, criminalizing its graffiti as public defacement and its music as disorderly "black noise." In spite of, or perhaps because of, its unruly reputation, hip hop has spread to become a lingua franca for youth around the world, spawning numerous subgenres and variants. Among these is Christian rap or holy hip hop-an inevitable development especially given the historic centrality of both Jesus and avowedly religious music in black communities.

Emerging in the mid-1980s, holy hip hop (also known under the monikers gospel rap, Christian rap, Christ hop, worsh-hop, and hip hope) refers to a musical genre and cultural movement that integrates Christianity and hip hop. ${ }^{2}$ As a musical practice used to articulate both a spiritual and social conception of self, gospel rap features biblically informed and Christ-centered lyrics over hard-hitting hip hop beats. The first holy hip hoppers came of age during the geopolitical and economic shifts of the post-civil rights years and comprise what many refer to as the "Hip-Hop Generation." 3 As this diverse subculture of predominantly black youth explored and converted to Christianity, they in turn brought hip hop worldviews and aesthetics to their worship practices. While Islam-and in particular, the Five Percent Nation-has historically been the most prominent religious ingredient in hip hop's diverse religious stock, explicit references to Christianity found a home in the steadily growing culture of holy hip hop, especially in Southern and West Coast hip hop scenes. ${ }^{4}$

But the story of holy hip hop in the City of Angels is unique. Since taking shape in the Inland Empire in 1986, it has developed alongside and in reaction to L.A. gang culture and the hypercommercialized West Coast gangsta rap that both critiqued and glorified the violence, drugs, death, and misogyny associated with it. The year following holy hip hop's initial Southland sounding, the 1987 antigang task force, Operation HAMMER, subjected black and brown youth to increasingly harsh state laws. The Los Angeles Police Department (LAPD) initiated an assault upon ten square miles of South Los Angeles between Exposition Park and North 
Long Beach. In a single weekend in 1988, a thousand police officers arrested 1,453 people. Referring to it as "Vietnam in the streets," historian Mike Davis remarked, "As a result of the war on drugs every non-Anglo teenager in Southern California is now a prisoner of gang paranoia and associated demonology." 5 By 1990 , over fifty thousand people had been arrested in raids, resulting in the most arrests of black youth since the 1965 Watts Rebellion. ${ }^{6}$ Meanwhile, members of the black clergy and black middle and upper classes wielded God's Hammer-the Bible-to make their own accusations about the moral depravity of inner-city youth in relation to God's law.

More upheavals of nature and culture followed. Four major earthquakes rattled Southern California: the Joshua Tree earthquake (M6.1), Landers earthquake (M7.3), and Big Bear (M6.5) earthquake, which all struck in 1992, and the Northridge earthquake of 1994 (M6.7). ${ }^{7}$ Mass flooding and fires ensued, causing severe damage throughout greater Los Angeles. The year 1992 also witnessed the rioting, looting, and arson that exploded in the wake of the Rodney King beating by five LAPD officers and their subsequent acquittal by a mainly white jury. ${ }^{8}$ In just three years, the Land of Sunshine endured some of the most costly and calamitous national disasters since the Civil War. ${ }^{9}$ Aside from $\$ 500$ million of flood damage, the 1992 riots cost the city \$1 billion, while the 1992 firestorms totaled \$1 billion and the 1994 earthquake caused a staggering $\$ 42$ billion of damage. In the face of repeated environmental eruptions, increasing poverty and unemployment, gang violence, police brutality, mass incarceration, intergenerational social alienation, and neoliberal efforts to make the state less responsive to people's needs, certain black Angelenos turned to holy hip hop for spiritual salvation, artistic expression, financial opportunity, and local community. In fact, many of the veteran L.A.based gospel rappers converted to Christianity in the years surrounding the four major earthquakes. Religious conversion became a way to make sense of and move through these disastrous circumstances and shattered grounds. Hip hop, again, became a way to transform violence and chaos into art and healing. But this time it was holy. And Pastor Graham, with his earthquake music, was speaking to this renewal of spirit in calamitous times.

Holy hip hop groups that emerged during the 1990s in L.A. took such names as Sons of Disaster, Sons of the Cataclysm, and Apokilipz, while the Comptonbased group Gospel Gangstaz named their reunion album The Flood. Even Tupac foreshadowed this "end of times" with his 1991 album 2pacalypse, in which the MC returns to destroy the earth with a final party for all those in the Thug Life. Los Angeles in the 1990s also witnessed the emergence of the production team, Earthquake Brothers, who produced many of the beats for Freestyle Fellowship's 1993 album, Innercity Griots - a classic of L.A.'s burgeoning underground hip hop scene. The press release for Holy Hip Hop, a 2006 documentary hosted by Christopher "Play" Martin (formerly of the rap duo Kid 'n Play), ended with the line: "With 
unimagined earthquakes and other fatalistic aspects permeating our very existence, holy hip hop, Christian hip hop, spiritual spitting, whatever you want to label it, will remain, just for the certain fact that it can uplift a downtrodden people."

To further develop Pastor Graham's metaphor of musical disruption, earthquake music signifies multiple and intersecting processes throughout the Southland: the "underground" explosion of holy hip hop in Los Angeles; the holy hip hop artists who live in predominantly black communities that sit astride the lethal Newport-Inglewood fault; the harsh apocalyptic beats that permeate gospel rap tracks; and the hip hop ministries that continue to shake up and polarize traditional church congregations and communities. The confluence of these developments in relation to the increase in conversions to Christianity by young hip hop "heads" in Los Angeles during the early 1990 s reveals an assemblage of practices, spaces, and traversals that only holy hip hop can sound out. ${ }^{10}$

To talk about holy hip hop as earthquake music is to explore how landscapes of urban peril and instability produce sound worlds that integrate styles such as gangsta rap, urban gospel, neo-soul, Jamaican dancehall, local street vernaculars, black preaching, and sampled soul, funk, and R\&B tracks. To talk about holy hip hop as earthquake music is to explore the ways that natural disaster, migration, racial segregation, civil unrest, and continued urbanization in Los Angeles formed a unique terrain for the emergence of devoutly religious subjects in the later part of the twentieth century. It is to talk about how American cities are giving rise not necessarily to secularization but to new forms of pop music worship both in the pulpit and on the streets. It is to talk about how this holy hip hop emerges not only in areas of unpredictable seismic activity, but is also a sonic and spatial practice that embraces a social imaginary of both turmoil and transformation. That's why Pastor Graham has to make this earthquake music.

CONVERSION, EARTHQUAKE MUSIC, AND SEISMIC SOUNDINGS

Religious conversion was a seismic event in the lives of gospel rappers-an event that sometimes struck suddenly like an earthquake or built up over time as repeated rumblings and aftershocks. Once converted, L.A. gospel rappers performed earthquake music - a sacred form of hip hop born from the grounds of a city shattered by social and environmental ruptures that in turn both moved and mended those very grounds. Holy hip hoppers navigated the "hip" and the "holy" in lyrical street-corner battles, during church services, and on hip hop dance floors, unsettling the boundaries between the church and the streets, missionizing and marketing, pop music and worship, performance and praise, entertainment and evangelism. These boundaries were not only performed and repositioned through a variety of tactics, but they were also lived, suffered, and resisted. 


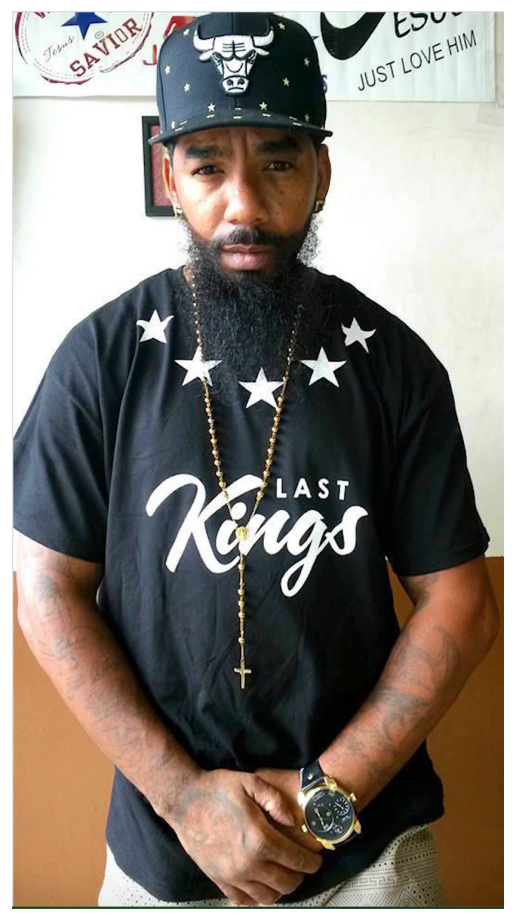

FIGURE 1. Pastor Graham at his clothing store, Ms. Anne's Sons, in Inglewood, c. 2016. Photo courtesy of Tiana Adams.

I offer seismic soundings as a term that links music, geography, and conversion. This idea is predicated on the understanding that music provides frameworks and tactics for navigating uneven and shifting grounds wrought with racial and religious fissures. L.A. gospel rappers made music that pulsed through and reshaped specific urban spaces in relation and reaction to episodes of environmental and social upheavals. They enacted a kind of musical tectonics. Just as seismic waves trigger earthquakes through the sudden movement of underground rock along a fault, gospel rap performances released transformative and ecstatic energies through the friction of hip hop and Christianity at the fault lines of so-called "sacred" and "secular" spaces.

The metaphor of earthquake music underscores a set of terminologies and concepts that both earthquakes and music have in common. Sound waves, like seismic waves, are measured by their amplitude and volume. Earthquakes, like music, have pulse effects and resonance effects. I pull out these connections in an effort to underscore both the sounded nature of L.A.'s shape-shifting, power-laden geography and the dynamic groundswelling force of holy hip hop. When certain cultural energies and musical practices coincide, shifts are produced that can be destructive. But within this destruction lies the possibility for transformation as 
well as the repositioning of social and physical borders. Earthquake music captures this power, thereby creating new centers and also new forms of marginality. ${ }^{11}$ In this way, holy hip hoppers also sound out underground or unseen geographies of black Los Angeles.

By integrating the fields of ethnomusicology, critical human geography, African American studies, urban studies, and anthropology, this book explores how ethnomusicological studies can expand discussions of the cultural politics of religiosity, race, and place, further probing how sound provides unique perspectives on contemporary urban religious phenomena. Drawing on over two years of continuous ethnographic research in L.A. from 2006-8 (and ongoing conversations over the past ten years) with gospel rappers, Christian DJs, pastors and clergy members, street evangelists, local activists, and fans, Holy Hip Hop in the City of Angels illustrates how conversion-as a religious, musical, and spatial practice-enables pathways and possibilities for black Angelenos amidst the radical postindustrial transformations, environmental cataclysms, and culture wars of Los Angeles in the late twentieth and early twenty-first centuries. The struggle of holy hip hoppers is not a politics of protest, but rather a politics of conversion. These street evangelists convert existing scriptures into hip hop rhymes, urban spaces into "airborne churches," and commercialized gangsta rap beats into anthems of praise. Here, conversion becomes both a religious transformation of healing and a daily practice of possibility within a multitude of constraints. While most academic studies of conversion focus on the human agent in relation to a religious change, I also attend to the conversion of nonhuman entities, material objects, sonic resources, and urban spaces. In this way, I conceive of conversion as both an analytic and an idiom of transformation.

For gospel rap artists, hip hop is not only a modality for expressing sudden or ongoing and messy religious conversions, but also one of the essential threads that links holy hip hoppers' pasts to their present. Hip hop in L.A. has become an idiom of widespread religious conversion, and earthquake music is how holy hip hoppers navigate and sound out invisible fault lines in the City of Angels. Just as the Northridge earthquake occurred along a fault that no one knew existed, invisible ruptures-social, musical, and physical-crisscross the shifting grounds of Los Angeles. Conversions, like earthquakes, can arrive as divine shakings along active faults. After they strike, people and places undergo seismic shifts and collective upheavals-new identities and new structures often emerge, even as these identities and structures are necessarily grounded in the same broken earth from which they are pushed upward. In following holy hip hop back to one of its initial soundings in Fontana, California, in the 1980s, we realize how this "Junkyard of Dreams" on the edges of the City of Angels became the birthplace of both the Hell's Angels and the early self-titled "Thug Angels" of holy hip hop. ${ }^{12}$ 
The specters of black poverty, hypersegregation, and racial terror have always haunted visions of L.A. as a Promised Land of the American Dream. African Americans in L.A. make up almost half of the city's homeless population, and approximately one in four black Angelenos live below the poverty line. ${ }^{13}$ And yet, L.A. has historically boasted one of the largest, long-standing, and politically powerful black populations in the nation, making up almost 10 percent of the region's overall population. ${ }^{14}$ When El Pueblo de Nuestra Señora la Reina de Los Angeles Del Río de Porciúncula (The Town of Our Lady the Queen of the Angels on the River Porciúncula) was established in the late eighteenth century under the Spanish flag, the majority of the Spanish founders were of mixed and African descent. ${ }^{15}$ By the time the United States seized control of California in 1846, the multicultural pueblo had become an expansive, ethnically diverse city with significant nonwhite geographies and an atypical and flexible racial order. ${ }^{16}$ Throughout the twentieth century, a steady influx of immigrants from Central and South America, Asia, and elsewhere transformed the Los Angeles metropolitan area into an urban mosaic with people hailing from all over the world speaking well over two hundred languages. The black population of L.A. had always been diverse, but by the early 20oos, new black immigrants from the Caribbean, Africa, and the Americas rapidly moved into the region. Nigerians, Ethiopians, Ghanaians, Belizians, Jamaicans, Haitians, and Trinidadians all clustered in and around existing African American communities. This diversity disrupted common assumptions about what constituted black L.A.

Holy hip hop continues to challenge unitary notions of blackness in L.A., painting a picture of black religious diversity not bound by certain orthodoxies. As holy hip hoppers continue to seek Zion-a spiritual home for which there is no single route-their migrant journeys can be traced from Caribbean childhoods to Los Angeles upbringings to missionary trips in Africa, and through reggae dancehalls, hip hop clubs, Nation of Islam meetings, political marches, and black Lutheran churches. Los Angeles is also home to a unique "musical mestizaje," creating cross-cultural currents that are particular to this city. ${ }^{17}$ For example, the gangsta rap that many gospel rappers previously performed is informed by the cholo-inspired attire, tattoo art, and lowrider culture of Southern California Chicanos, revealing how black and brown diasporas also find their overlap through holy hip hop. ${ }^{18}$ I explore how the multiple diasporic routes that holy hip hop brings together speak to the persistent search for Zion through black religion and popular music. Given the dearth of scholarly works that link significations of Christianity, Islam, and Rastafarian culture in black popular expressions, Holy Hip Hop in the City of Angels offers a unique perspective on how these religions intertwine in people's everyday musical experiences. ${ }^{19}$ Hence, I allow music's role in the mutual construction of both diasporic urban spaces and new religious subjectivities to resonate. 
Holy hip hop subjectivities assemble a unique arrangement of spiritual, musical, and political sensibilities informed by positions of race, gender, and class. ${ }^{20}$ While holy hip hop is not an overtly politicized movement, many of the gospel rap artists featured in this book grew up in hip hop culture, amidst the deeply wrought race politics of L.A. in the 1980 os and '9os, and under parents who honored and explored both the militant Muslim teachings of Malcolm X and the Christian peace-seeking philosophies of Martin Luther King, Jr.-in addition to other spiritual traditions. Young black Angelenos used gospel rap to interface with diverse black religiosities and navigate the complicated social and spiritual realities that they confronted in their daily lives. As Pastor Graham said, finding God was what allowed him to "move through these streets" and gospel rap was what moved the ground he walked on. In the spirit of hip hop's unruliness and extending the legacy of Christian liberation politics, gospel rap provided new possibilities for engaging with multiple key black cultural entities-African American churches, gospel music markets, hip hop scenes, and political movements from Civil Rights to Black Power to Black Lives Matter. ${ }^{21}$ Conversions, of all kinds, opened up these possibilities. But more than anything, gospel rap gave young hip hop heads seeking God a way to participate in the cultural movement and musical language they knew so well: hip hop.

\section{WHAT IS HOLY HIP HOP?}

Gospel rap, on the one hand, is an extension of black sacred musical styles, considered a subgenre within the ever-proliferating sound world of contemporary urban gospel. ${ }^{22}$ It reaffirms music's historically central role in African American religious culture as a medium of worship and community building. On the other hand, gospel rap is an expression of hip hop aesthetics and practices associated with street life and, oftentimes, gang culture. Gospel rappers remain committed to "taking the gospel to the streets" as well as seeking relationships with "unchurched" and marginalized populations in ways that traditional churches and gospel music artists have failed to do. This is in part due to how hip hoppers have become holy hip hoppers: in most cases, their initial and primary commitment was to hip hop music and culture; then, they gave their lives to Christ. As L.A. holy hip hop artist Soup the Chemist once told me, "I'm not a Christian rapper. I'm a rapper who's a Christian. I was a rapper first and then I became born-again." While many of the gospel rappers I met attended church services occasionally as youth, most of them would say that they were first baptized in the streets of Los Angeles. This is why their holy hip hop sounds more like gangsta rap than gospel music.

Musically, gospel rap is squarely planted in the sound world of hip hop, embodying a diversity of regional hip hop styles and variations from Southern bounce to Los Angeles gangsta rap to New York street aesthetics. There is no singular 
"holy hip hop" sound. Nor are there specific sonic signifiers that distinguish holy hip hop from "secular" rap. Holy hip hop, like most hip hop music, is driven by the dynamic fusion of beats and rhymes. Gospel rap beats, whether created from samples, music software programs, and/or live instrumentals, provide the musical foundation over which gospel MCs spit (i.e., rap) their spiritually inspired lyrics. It is the lyrics - usually expressions of belief or personal testimony-that make holy hip hop holy. Despite the importance of lyrics in distinguishing holy hip hop as a sacred genre, I do not analyze the religious meanings expressed in gospel rap lyrics at great length. Most scholarly studies on hip hop focus on lyrical analysis-a tendency that has often produced limited interpretations and discussions about hip hop music and culture. To avoid this tendency, I focus on the musical and spiritual practices of holy hip hoppers. While I describe the sound of certain holy hip hop tracks and performances throughout the text, I encourage readers to explore the musical links listed in the back of the book in order to experience the music itself.

Stephen Wiley is recognized as the first artist to commercially record and distribute a gospel rap cassette with his 1985 release Bible Break-a fact acknowledged by California Christian rapper T-Bone in his song "Our History" on his own 2002 album entitled GospelAlphaMegaFunkyBoogieDiscoMusic. Hailing from Oklahoma, Wiley is often referred to as the "Godfather of Gospel Rap." While the title track of Wiley's album reached the \#14 spot on Christian radio in 1986, many gospel rappers have called his style "soft" or "homogenous." New York's Michael Peace followed in 1987 with Rock It Right and Dallas's P.I.D. (Preachers in Disguise) in 1988 with their Run DMC-inspired street style and the addition of clergy collars. Two years later, multiracial Christian rap trio DC Talk released their selftitled debut album. The late Danny D-Boy Rodriguez emerged on the scene with Plantin' a Seed. ${ }^{23}$ While mainstream media and press generally focus on these few artists as the forerunners of holy hip hop, the Los Angeles-based gospel rap group SFC (Soldiers For Christ) was also producing gospel rap as early as 1986. Early Christian rappers from the Southland, such as Gospel Gangstaz, L.A. Symphony, the Dynamic Twins, and I.D.O.L. King, have generally not been acknowledged among the likes of Wiley, Peace, DC Talk, and Rodriguez.

Although sufficiently below the radar of mainstream visibility and simultaneously marginalized by both religious music circuits and commercial hip hop scenes, the holy hip hop movement now boasts its own annual awards show, several national festivals and conferences, online music archives, a slew of hip hop preachers, independent record labels, numerous radio programs, and hip hop ministries and churches-a growing trend most recently celebrated by USA Today, Vibe, Vanity Fair, and numerous local newspapers. The increasing number of FM, internet, and satellite gospel radio stations throughout the 199os and early 2000 s has been critical to exposing gospel music audiences to holy hip hop. Categories for gospel music awards have been expanded to include Christian 
rap by the National Academy of the Recording Arts and Sciences (the Grammy Awards), the Stellar Awards, and the Gospel Music Awards.

Christian rapper Lecrae won the "Best Gospel" album for his 2012 release, Gravity, at the 2013 Grammy Awards, "Best Artist of the Year" at the 46th Gospel Music Association (GMA) Dove Awards, and "Best Gospel Artist" at the 2015 BET Awards. Lecrae's awards (all won in religious categories) reveal that while gospel rap sonically registers as hip hop, the audience it cultivates commercially is a holy one. Lecrae's recent success, along with his 2015 performance of "Welcome to America" on the Tonight Show with Jimmy Fallon and 2016 performance at the BET Hip Hop Awards, has brought unprecedented exposure to the subgenre in the years since I first began this research, and contributes to its slow but steady commercialization.

Despite these developments, Christian rap has generally not been well received by mainstream or commercial hip hop culture. "Secular" hip hop artists, fans, and industry professionals often view the infusion of a hip hop sensibility with Christian morals as gimmicky, soft, and musically subpar. In some ways, holy hip hop artists find themselves in a triple bind: considered musical mavericks in the church, corny Bible-thumpers in the streets, and criminal youth by law enforcement in the hyper-ghettos of L.A., they are constantly fighting against accusations that their ways of being and expressing are blasphemous and/or inauthentic. These competing critiques constitute their struggle to move freely across social, spatial, and sonic borders-a border crossing that has generally been the norm in black music.

Holy hip hop practitioners are part of a genealogy of African American artists who have blurred the lines between the "sacred" and the "secular" within churches, nightclubs, and the music industry at large. Holy hip hop, as it extends these practices of musical border-crossing, is really nothing new. Pop stars such as Ray Charles, Sam Cooke, Al Green, Aretha Franklin, Curtis Mayfield, Stevie Wonder, and Donny Hathaway, among others, merged gospel music sensibilities with R\&B and soul. ${ }^{24}$ While pop music has drawn inspiration from the church, black Christianity has long absorbed the sounds of popular music. Gospel icons such as Thomas Dorsey, Andrae Crouch, the Staple Singers, the Edwin Hawkins' Singers, and Kirk Franklin have all incorporated "secular" music forms into "sacred" worship, whereas Sister Rosetta Tharpe took church music to the nightclub. Styles such as the blues, jazz, R\&B, soul, rock, funk, and even punk music have found their way into the church, but generally not without a thunderous backlash of skepticism that has often re-polarized religious discourses on the permissibility of sacred/ profane border crossing.

One is immediately reminded of the shocked and horrified reactions of churchgoers when pianist Thomas Dorsey brought blues music into the church in the 1920 s and '3os, boldly ushering in the sound that would become standard gospel 
music. ${ }^{25}$ Similarly, some members of an older generation as well as more traditional adherents of black Christian worship have expressed an aesthetic aversion to the "noise" and iconography of hip hop, seeing it as an unorthodox presence in the church. For them, gospel rap literally brings the street sensibility of Bronx block parties and schoolyard battles associated with early hip hop into the sanctuary. Despite hip hop's impressive ingenuity, it has not broken free from some of its unlawful and immoral associations. In Los Angeles, gospel rap also carries the controversial stigma of West Coast gangsta rap and the sounds of black masculine rage and pleasure that accompanied it-sounds that were met with both forceful condemnation and unprecedented commercial success.

And so, perhaps, nothing quite as unabashedly commercial as hip hop has entered the pews, nothing that displays materialism and violence so dramatically or employs such forceful modalities (e.g., scratched vinyl, breakdancing, explicit lyrics). And perhaps this is why G. Craige Lewis of EX Ministries, an African American preacher who has been deemed holy hip hop's number one "public enemy," preaches his anti-hip hop gospel to congregations of one to two thousand people every weekend. When Lewis finishes his sermons, he calls congregants who have purchased hip hop CDs to pile them on the altar, where they will be smashed to pieces, sometimes with sledgehammers. Those with tattoos-what Lewis calls "marks of Cain" and "emblems of the occult religion of hip hop" - are called to kneel before the altar so that Lewis can pray for God to save their souls before it's too late. ${ }^{26}$ It is not surprising that some gospel hip hop artists choose not to perform in church.

The emergence and rise of holy hip hop coincides with both national and global revivals of fundamentalism, contemporary apocalyptic movements in the United States (especially Los Angeles) at the turn of the century, trends toward religious pluralism, and the new sense of radical individualism ushered in by 1980s consumerism. In this pluralizing environment, there is both a greater openness and increased vehemence towards new, unorthodox, and individualized expressions of religious belief. In addition, holy hip hop's minimal yet slowly increasing presence in the commercial marketplace has been made possible by the growth of Christian Lifestyle Branding, ${ }^{27}$ Prosperity Theology, and the proliferation of "hip" religious commodities (e.g., "Jesus Is My Homeboy" and "Mary Is My Homegirl" T-shirts, diamond cross medallions, etc.) ${ }^{28}$ Cornel West argues, "Never before has the Nation (or world) been so seduced by markets and so hungry for spirituality," which begs his haunting question: "Why is the United States the most marketdriven and religious nation of modern times?"29 Indeed, there are myriad instances of religion being expressed through popular culture, from sports events to movies, TV shows, and large-scale concerts and festivals. Scholars continue to identify the presence of religious and ritual behavior in contemporary musical youth subcultures and analyze how popular music is an arena through which religion 
is mediated..$^{3 \circ}$ Given this renewed presence of religion in the public sphere, both in the United States and globally as expressed through mass social movements and antigovernment protests, we must acknowledge the extent to which postwar modern individualism and continued urbanization in American cities are giving rise not to secularization, but to new modalities of worship both inside and outside the institutional context and creating expanded possibilities for the emergence of devoutly religious subjects.

That said, for the purposes of this book, I am less interested in situating holy hip hop within larger national trends in institutional religion and evangelical Christianity. While I draw occasionally from religious studies scholars who address hip hop culture, ${ }^{31}$ I do not prioritize comparisons between holy hip hop and other genres of Contemporary Christian Music (CCM), such as Christian rock, Christian heavy metal (or "Heavenly Metal" as some have dubbed it), and Christian New Age..$^{22}$ In addition, the majority of the musicians I worked with were grassroots artists that often also maintained day jobs. As such, they were mediating a much different set of situated circumstances, localized constituencies, and shifting locations than commercially viable CCM artists in California and beyond. The economic, racial, and gendered differences and asymmetries of power between commercial CCM and grassroots gospel hip hop are significant, warranting more culturally and geographically specific readings.

\section{LOCATIONS AND LOCOMOTIONS}

Occasionally, I will draw links to holy hip hop in cities such as Atlanta, Harlem, Chicago, and Houston, but I will focus on how Los Angeles's specific arrangement of earthquakes and natural disasters, populations, policing practices, violent crime, factory closures, and gang culture makes holy hip hop in the City of Angels a distinct phenomenon on its own terms. The sprawling, fragmented quality of Los Angeles's geographic terrain-a decentralized, polynucleated, and automobile-oriented city-poses different spatial and organizational challenges for studying holy hip hop culture. What does it mean for holy hip hop to be emplaced on grounds that are so unstable and constantly moving?

To study cultural phenomena in Los Angeles, one must acknowledge a specific tension about the experience of place-that is, place as both physically situated and shape-shifting, both located and locomotive. To this end, I have found several different bodies of literature to be useful. While the frameworks of urbanization and "suburbanization" as proposed by Edward Soja, Allen Scott, and Mike Davis of the Los Angeles School of Urbanism have helped me situate holy hip hop within historical sedimentations, state policies, and patterns of African American migration specific to Southern California, I depart from their emphasis on political economy to also consider the cultural politics of place. ${ }^{33}$ In trying to account for the way 
that power relations, social dynamics, and everyday practices produce our sense of space and place, I have looked to the field of critical human geography, and specifically the work of British and French geographers such as Henri Lefebvre, Michel De Certeau, Doreen Massey, Michael Keith, and Steve Pile. ${ }^{34}$ Synthesizing the above work, I aim to hold the tension of physical locatedness and the unfixed, relational aspect of space. ${ }^{35}$ To understand urban life is to deal with the empirical aspects of specific places, the abstract notions and stories that we attach to those places, and the social relations and activities that create and define them.

Given the challenge of holy hip hoppers to find spaces of acceptance and belonging - to find Zion-I became particularly interested in tracking when and where holy hip hop was performed. This prompted a deeper curiosity about the mediating effects of place on music and vice versa. There is a rich and expanding literature that connects notions of space and place to music. ${ }^{36}$ While many of these studies have provided historical and ethnographic accounts of music's relationship to specific localities, few of them engage directly with scholars from critical human geography, and in this way, do not connect music to the social interactions and spatial practices that shape space. ${ }^{37}$

City space also shaped the social interactions and spatial practices of this musical ethnography. It shaped how holy hip hoppers and I both lived and conducted our respective work in the city, allowing for certain kinds of movement and prohibiting others. Spanning 4,06o square miles, Los Angeles County is the most widely dispersed metropolis in the country, while Los Angeles city proper covers 469 square miles. And yet, until the late 1970s, the majority of black Angelenos lived in a few densely populated neighborhoods in South Los Angeles-still commonly referred to as South Central despite undergoing an official name change in 2003. During the years I lived in Los Angeles, holy hip hop-while concentrated in a handful of neighborhoods-was spread across this vast metropolis. Inglewood became one of the main geographical foci of my research because it was home to the Hip Hop Church L.A., but no central hub existed. Holy hip hop's fragmented, translocal community contributed to its uniquely ruptured soundings and sensibilities, but also to its capacity to span multiples spaces..$^{38}$

Throughout my research, I conducted interviews and attended holy hip hop events, concerts, and church services across greater Los Angeles-from Lancaster to Long Beach, Inglewood, Moreno Valley, Compton, Rancho Cucamonga, Fontana, Leimert Park, Watts, Santa Monica, downtown Los Angeles, Carson, Culver City, Bell Flower, Gardena, and Northridge. In the following chapters, I will illuminate how these disparate localities within Southern California are linked to one another through musical and spatial practices, constituting a kind of audibly rendered (sub) urban archipelago. ${ }^{39}$ Los Angeles, long touted as a diffuse concrete sprawl epitomizing the ethics and aesthetics of "car culture" immortalized by the G-Funk-inspired gangsta rap of Dr. Dre and Snoop Dogg, is often overlooked as a place of sociality, 
spirituality, and artistic communion..$^{40}$ In Los Angeles, hip hop and automotive spaces are inextricably intertwined. The car became a critical locomotive and location during my research on holy hip hop-a process that was as much a pedestrian and vehicular voyage through L.A.s archipelagic geography as it was a musical journey through sound.

I began to see my research as an effect of ethnographic locomotion as much as ethnographic location. ${ }^{41} \mathrm{My}$ research field was a mobile, heterogeneous terrain of encounter comprising many fields as opposed to a physically bounded space. My ethnographic experience was one of navigation-navigating diverse populations and urban spaces, but also the borders between sacred and profane musical practices and vernaculars. Travel between various research sites and fields throughout Los Angeles became as critical to my understanding of gospel rappers as spending time with them in fixed locations.

A significant amount of my field research and ethnographic work-conversations, observations, listening to music, processing information and experiences-was conducted from and inside automobiles. Over time, I began to treat driving, both alone and with holy hip hoppers, as an interdisciplinary methodology that privileges practice and traversal. Driving to particular events and interviews, I witnessed the physical Los Angeles that my informants did: the same streets, signs, buildings, churches, communities, and hip hop spaces that made up their current daily movements as well as their pre-gospel rap pasts. The specific routes I took to events in Inglewood, Watts, or Compton provided much different experiences of urban geography and also helped to defetishize space. The mental geography created by driving into Inglewood from the 405 Freeway along Manchester Boulevard is very different than the one created by driving south down Sepulveda Boulevard. Different routes to and from holy hip hop locations highlighted different spatial segregations, different densities of population, different ethnic and racial groupings, and different kinds of commerce. There are many L.A.s-many versions of the city. Depending on whether or not I took streets or highways, chose to cut through certain neighborhoods or even drive down specific blocks, I witnessed the compression and exaggeration of social difference in distinct ways. By driving these various routes, I was able to get a better sense of how holy hip hoppers experienced negotiations of time, space, and bodies from the quasi-privacy of cars, and how our travel and movement across the city was raced and gendered in specific ways.

We listened to holy hip hop tracks on their car stereos. We talked about things we saw on the streets. Cars were where a lot of misrecognitions of gospel rappers took place as well. From the passenger side of their rides, holy hip hop music blasting out of the windows, I observed how black men playing hip hop music at loud volumes are often seen and heard as gangsters, gangsta rappers, or more generally, criminals. That is, driving around Los Angeles with gospel rappers was often 
where I witnessed firsthand how they were interpellated by both police and city residents. The hypervisibility of black bodies in commercial media has rendered invisible important truths about everyday racial subjugation.

Christian rapper Lecrae, on his 2006 track "Jesus Muzik," raps about the confused reactions he receives as he drives his pale yellow convertible down the street:

Plus I'm bumpin dese Jesus beats whenever they seein me

People lookin all confused, cuz every one of my tunes is screamin Jesus peeps

Then the hook, which features a "screw" technique of making the words super low in register and hyper-slow in delivery, drops in: "Ridin wit my top down listenin to this Jesus music." Fast driving cymbal hits gallop across a surging and synthesized melodic loop. Lecrae refers to the bewilderment that his music and his identity create for those witnessing him ride through the neighborhood "bumpin dese Jesus beats." The song's instrumentals, like most gospel hip hop, sound just like any other commercial hip hop track. Expecting to hear the profane language so common to gangsta rap and other forms of commercial hip hop, passersby often do a double take upon hearing the religious message booming from his car speakers.

More spiritual clues awaited inside the cars of gospel rappers. Gospel rap automobiles also doubled as mobile spiritual altars traversing the city, leaving the resonances of "Jesus beats" in their wake. Crosses dangled from their rearview mirrors. Small pictures of Jesus were affixed to their dashboards. Cars served as a portable "merch table" or literal marketplace of holy hip hop music sales. Gospel rappers sold their homemade CDs out of the storefront of their car trunks at flea markets, in church parking lots, or on street corners. It was also important to play holy hip hop music on car stereos as this was often the intended listening environment. While most L.A. residents do not necessarily own homes, many own cars and spend a significant amount of time in them.

The cars of holy hip hoppers became spaces of rumination, prayer, music making, consumption, marketing, and missionizing. They became a part of L.A.'s shifting landscapes as they were converted into roaming offices, record stores, or music studios. I would like to highlight the ways in which the "automobility" of this particular ethnography became both a literal and symbolic vehicle for grounded forms of listening, looking, mapping, relating, and witnessing-a vehicle for driving as interdisciplinarity. "Automobility" was how the archipelagic geography of Los Angeles was connected. Earthquake music was how gospel rappers navigated those moving grounds, even as they let Jesus "take the wheel."

Los Angeles's development coincided with the American automobile era. ${ }^{42}$ Studies and writing abound on the pedestrian experience or the act of strolling through the city, whereas cars have been absent from the analysis of the urban. ${ }^{43}$ And yet, cars and the modes of mobility they make possible reconfigure both 
urban and suburban life and enable certain kinds of "dwelling, traveling, and socializing" in the "automobilized time-space." ${ }^{4}$ While scholars and Southland residents alike have often lamented the privatizing, segregating, and alienating effects of the car on city life-particularly in relation to the preservation of public spaces and associational life-the car has been hailed as an emancipatory object and transcendent space in African American cultures. This is especially true for Los Angeles-based gangsta rap. Paul Gilroy, critiquing what he calls "American automotive utopianism," 45 argues that African Americans' experiences of "racial terror, brutal confinement, and coerced labour must have given them additional receptivity to the pleasures of auto-autonomy as a means of escape, transcendence, and, perhaps fleetingly, also of resistance." ${ }^{46}$ But the search for such automotive pleasures has often resulted in ostentatious displays of conspicuous consumption.

Returning to the gospel rappers whose automotive altars bump "Jesus beats," how can we understand cars as the quintessence of consumer capitalism as well as important spaces of spiritual practice? Further, how does the automobility of holy hip hop culture in L.A. make possible certain movements across the city and demonstrate how specific music cultures and racial subjects are constrained by local geometries of space and power? What kinds of "black cultural traffics" are produced through the mobilities and immobilities of holy hip hop culture? ${ }^{47}$

\section{WHAT IS THIS “BLACK” IN HOLY HIP HOP?}

To say that a significant part of my research was conducted in cars is not to imply that holy hip hoppers exclusively "trafficked" in the local, or even the regional. ${ }^{8}$ While most holy hip hoppers clearly defined themselves as Christian, their everyday lives and practices revealed the mixing of diverse transnational spiritualities and sound worlds: gangsta rap, urban gospel, Nation of Islam-inspired hip hop, Five Percent Nation lyrical tropes, Jamaican dancehall, African American preaching, street vernaculars, and sampled soul, funk, and jazz music. Throughout the book, I foreground these sonic and linguistic intersections of Islam, the Rastafarian movement, and Christianity in the lives of gospel rap practitioners-intersections that highlight sympathies and circulations among black religious forms as they challenge Christianity as a fixed category. Sometimes, holy hip hop expressions that are inflected with multiple religious sensibilities are done so in a self-conscious manner, such as a Barbadian-born Christian rapper's identification as "The Pastorfarian." Most often, such expressions are highly encoded and unintentional, illustrating below the radar cultural intimacies and borrowings.

Many scholars have argued the point of black American diversity and heterogeneity as it is linked to the cultural repertories of the African diaspora. ${ }^{49}$ While this point may seem obvious, it deserves restating, as the tendency to equate race and nation in black American musical performance remains seductive from many 
different vantage points. Riffing on Stuart Hall's well-known essay, "What Is This 'Black' in Black Popular Culture?" I argue that this "black" that we hear echoing through holy hip hop is an expression not just of multiple L.A.'s but also of multiple Americas enmeshed in the soundscapes of the Caribbean and Africa..$^{50}$ Holy hip hoppers might not define themselves as part of a diaspora, but their discourses and practices transcend biologically driven and ahistorical renderings of race and nation.

The diasporic routes and resonances of gospel rap suggest how an ethnomusicology of contemporary black sacred music may expand the self-definition of academic fields such as American Studies and African American Studies. That is to say, while the African diaspora has often been theorized through black popular music, studies on black sacred, and specifically Christian, music also have a theoretical intervention to make vis-à-vis the black Atlantic. Los Angeles-based gospel rap, in somewhat paradoxical fashion, helps to unsettle the frame of black American particularism, especially in regard to notions of black Christian uniformity and U.S. hip hop superiority as it is circumscribed by national boundaries..$^{51}$ But this focus on the diasporic routes and resonances of holy hip hop does not mean that it loses its cultural identity as African American..$^{2}$ Many of the global connectivities sounded through holy hip hop take shape in what we consider highly localized spaces, such as Inglewood and Compton-spaces that are also iconically rendered as black American in the popular imagination.

Here, I must return to the premise of black American diversity and heterogeneity. ${ }^{53}$ Holy hip hoppers have developed a position that certain kinds of black Christian orthodoxies and respectability politics have deemed incomprehensible. Their music poses a challenge to existing racial and moral hierarchies as it radically expands notions of black worship. While scholars have often described black popular culture as a diasporic and contradictory space, studies of black religion have generally been articulated through a nationalist frame that does not acknowledge the internal splintering within African American communities, nor the presence of certain global syncretisms and linkages.

In trying to challenge assumptions of African American homogeneity, there is always the danger of reifying the very categories and signifiers one attempts to unsettle. The reification of both "the black church" and the signifier "black" is something that troubles me in my own work and the work of others. The study of black religion has been, as Anthony Pinn states, "hopelessly biased towards Christian sensibilities and themes", leading to "the myopic depiction of black religion as synonymous with the Black Church tradition." ${ }^{54}$ As the holy hip hop stories and soundings herein suggest, the church is a highly mobile, porous, and transnational configuration composed of many different individuals, communities, organizations, governing principles, agendas, sentiments, musical genres, and ministerial practices. Sometimes "the church" can even refer to a particular state of mind or 
religious awareness; other times it refers to a shared space of intimacy between a group of people and/or God. Rarely does it simply refer to the actual structure of a freestanding church building that houses a homogenous all-black congregation. I am interested in the religious sensibilities, experiences, and practices of holy hip hop as opposed to institutional structures of Christianity.

Meanwhile, the debates surrounding African American Christianity (i.e., resistance vs. accommodation, liberation vs. oppression, white vs. black) have also failed to yield more complicated and historically up-to-date understandings of the diverse experiences associated with being religious, musical, and African American in America. ${ }^{55}$ Taking a complex, diasporic (and locomotive) framing of black Christianity seriously, we must then consider how holy hip hop is implicated in many global histories of racial and economic injustice as well as black freedom struggles that have engendered connections, conversions, and contradictions among people of African descent. In this way, gospel rap-like the spirituals and hip hop-is part of a far-reaching arc of black theological and liberation thinking from James Cone to Black Lives Matter..$^{56}$

Another influential and deadly framing of black Americans has been the "culture of poverty" - a postwar phenomenon gaining traction in the 1970s that has been hegemonic in the social sciences and domestic politics as expressed through conservative policies on welfare. ${ }^{57}$ The "culture of poverty" posited that poor people, especially people of color, exhibited monolithic and pathological beliefs and behaviors such as being unmotivated, violent, abusive of drugs and alcohol, and linguistically deficient, among others. Many scholars have critiqued the fatalistic myths and stereotypes articulated and reinforced under this model, providing real-world data that goes against the corrosive ideas associated with the "culture of poverty." Holy hip hoppers provide another real-world example that challenges and disrupts these long-standing theories about the cycle of poverty, the perpetuation of the underclasses, and more specifically the pathologies associated with gangbanging and gang cultures. ${ }^{58}$ Conversion, as a constitutive component of earthquake music, is not just an important focus of this book, but is also a generative analytical tool for examining the transformative practices and effects of holy hip hop that seek to break free of such demonizing and incarcerating discourses.

\section{THE POLITICS AND PRACTICES OF CONVERSION}

During most of my interviews with gospel rap artists, talk of conversion took center stage. For L.A. gangsta rappers-turned-gospel rappers, holy hip hop nurtured a politics of conversion that attempted to move beyond the polarizing vocabularies of "secular" and "religious" in order to create passages across the fault lines of generation, genre, and geography amidst L.A.'s particular conditions and constraints. Instead of getting boxed into either hip hop or Christianity, 
they converted themselves, their music, and their surroundings into something wholly new. Practices of conversion, whether they involved a spiritual change, a change from one viewpoint to another, a physical transformation, a change in function, or even just a turn of phrase, made possible certain moments, sites, and experiences of transition, rebirth, and changeover. ${ }^{59}$

My interest in conversion emerges out of the centrality of these conversionary practices in the lives of holy hip hoppers-conversion as a religious transformation, a musical transposition from secular rap to gospel rap, and a spatial tactic of creatively repurposing the urban environment for spiritual aims. Gospel rappers also converted common hip hop aphorisms, slang terms, and lyrics into expressions evoking religious connotation. When they used the term $\mathrm{MC}-\mathrm{an} \mathrm{ab}-$ breviation for "Master of Ceremonies" but in hip hop cultures thought to mean "Microphone Controller"-they understood this to signify "Minister of Christ." In a series of similar linguistic re-significations in holy hip hop, "player hater" became "prayer hater," the lyric "Baby Got Back" was changed to "Baby Got Book," and "BYOB" was an acronym for "Bring Your Own Bible" instead of "Bring Your Own Booze." These clever linguistic turns, what I refer to as flippin' the script(ure), were part of a larger set of multimodal and intersecting conversionary practices across varied temporal and spatial terrains in which gospel rappers harnessed conversion as a technology of transformation in order to precipitate acts of rebuilding, reinvention, and integration. ${ }^{60}$ In addition to converting to Christianity, young black hip hop artists - some of L.A.'s most policed and yet simultaneously ignored citizens-enacted spiritual, spatial, and sonic transformations through their seismic soundings.

Conversion is a word at once practical and irrational, objective and subjective, worldly and otherworldly, shadowy and illuminating. It is the multi-resonant nature of conversion-its capacity to enunciate and join together bodies and beliefs, politics and the divine-that makes this word so ambiguous and powerful. The vocabularies and phrases signifying conversion are vast and equally vague, aggregating an active and ever-changing lexicon of conversion-related expressions. I got saved. God got a hold of me. I've been delivered. Born again. ${ }^{61}$ Born from above. Raised from the dead. In this way, conversion is both an experiential idiom of religious transformation and a generative concept shaping everyday idioms and expressions. Interestingly, converts rarely use the term to refer to their exact moment of conversion; rather, conversion has become a way to understand this process after the fact, both instant and gradual, which gives insight into the importance of narrativizing, retelling, and interpreting conversion experiences.

Scholars have exposed and debated the challenges in using "conversion" as an analytical tool. ${ }^{62}$ The Comaroffs argue that the term conversion "carries a commonsense European connotation" that oversimplifies a complex and partial process. ${ }^{63}$ They question the extent to which "conversion" fully grasps "the highly variable, 
usually gradual, often implicit, and demonstrably 'syncretic' manner in which social identities, cultural styles, and ritual practices" are transformed by evangelical encounters. ${ }^{64}$ Acknowledging the potential of conversion to mask, simplify, and naturalize complex social processes, I have tried to avoid the teleological tendency of conversion, which often posits conversion as a final destination or quest for meaning in the face of modernization. I have also attempted to disentangle the word itself from holy hip hop practices of conversion in order to position conversion not as a definitive breach with an amoral and "unsaved" past, but rather as a set of ongoing transformative events, acts, and narratives-a series of rumblings expressed through earthquake music that "shakes our souls and moves the ground we walk on."

The etymological origins of the word contain many spatial resonances: to turn, return, turn around, reorient, and change directions. Conversion is a movement, "a form of passage", and a "turning from and to" that can open a path to a particular future, to humanity, or to belonging. ${ }^{65}$ As anthropologist Diane AustinBroos argues, "Conversion is a type of passage that negotiates a place in the world. Conversion as passage is also quest, a quest to be at home in a world experienced as turbulent or constraining or, in some particular way, as wanting in value." ${ }^{66}$ Conversion is not a quest for utopia, but rather a quest for "some place rather than no place." ${ }^{\prime 6}$ It is the creation of new, provisional, and often mobile places of belonging outside of the church or the club that constitutes gospel rap's unique geographies of conversion-geographies of mobility not captured by city maps or visual renderings of black L.A. Conversion, like automobility, is also a way to link the archipelagic spaces of the Southland through passages and traversals. And like driving through the city, holy hip hop conversions involve the navigating of multiple routes, mergings, blockages, and impasses.

In the following chapters, I explore articulations and manifestations of conversion in the lives of holy hip hoppers-rites/rights of passage, geographies of conversion, and the evangelical hustle. Each of these ideas builds on the concept and practice of conversion, exploring the intentional and unintentional conversions of peoples, places, objects, and sounds through earthquake music. Here, conversion illuminates how the cultural, political, and religious are interrelated in holy hip hop practices and how those practices emerge from structures of discrimination and stigmatization that are at once highly localized and resoundingly global.

\section{FINDING ZION, SOUNDING PLACE}

The term Zion has often been used by gospel rappers to denote a place of spiritual and musical belonging that was not necessarily afforded those who participated in both hip hop and Christianity. Not a physical place, per se, Zion was an 
abstraction, a feeling, "a quest to be at home" amidst L.A.'s Babylons. Zion and Babylon are spatial imaginaries that have been significant in the formation of transatlantic solidarities as well as multiple searches for liberation and salvation that no doubt implicate imperialism, colonialism, and African dispersal. Holy hip hoppers sounded these global connections as they simultaneously localized these biblical terms to signify the harsh realities of the L.A.'s postindustrial landscapes, racial segregations, policing practices, and pop culture excesses. ${ }^{68}$ For holy hip hoppers, the Zion they sought was not about the formation of statehood or even a return to some distant motherland; rather, it was about creating the conditions of possibility for certain kinds of black becoming. Holy hip hop's search for Zion involved a series of twists and turns instead of the notion of simple return to a distinct homeland. Conversion was about conceiving of more liberated Afro-futures as opposed to reclaiming roots.

Holy hip hop subjectivities were produced in and through a number of different locations-street corners, churches, parks, schoolyards, cultural centers, clubs, and theaters-but more importantly, gospel rap artists, in their quest for Zion, created alternative spaces that linked the seemingly disparate elements of Christianity and hip hop. These spaces assembled and blurred racial, spiritual, and musical geographies, producing heterogeneous social arrangements that were often highly mobile and fleeting. They were not permanent physical locations. In this way, I draw from Jacqueline Nassy Brown's assertion that place must be understood "first and foremost as an abstraction, not a set of physical properties just there for the eye to see." ${ }^{69}$ Holy hip hop's geographies of conversion were constituted more through spiritual ideas and musical sounds than physical properties and visual forms. As such, they denaturalized the idea of place as matter, even as the very real material conditions of specific places were crucial in the formation of gospel rappers and their music - and even as the volatility of L.A.'s physical and social landscapes in the 1990 s were wreaking havoc on the lives of its residents.

Holy hip hop's geographies of conversion often left no visual trace, sometimes fading out as quickly as they were sounded into existence. These sonic geographies spoke to the larger invisibility and impermanence of multiple black L.A.s. Recall the painful transformation of Central Avenue from a dynamic epicenter of black music and interracial socialization to a desolate and abandoned thoroughfare. Once the heart of Los Angeles's African American community during the 1920s50s, Central Avenue was home to a vibrant jazz and R\&B scene that flourished until the LAPD carried out a series of systematic and racially motivated crackdowns on the nightclubs and bars, forcing many of them to shut down. Many histories of black Los Angeles, although now invisible to the eye, reside in genealogies of sound. Unearthing these histories involves acts of listening rather than seeing. Here, popular music practices are generative of critiquing academic tendencies that perpetuate the hegemony of vision. 
As storms, earthquakes, and riots altered and destroyed the physical terrains of greater Los Angeles, holy hip hoppers began to sound out new geographies of possibility in their aftermath. Their expressions made audible certain histories, practices, places, and daily realities, giving prominence to the experience of place as sounded. Their expressions mapped the complex historical, spatial, and political relationships between the 1992 L.A. riots, Ice Cube's Nation of Islam-inspired song "We Had to Tear This Muthafucka Up," and the "House of Judah" church standing on the former site of a Western Surplus gun store. In particular, the entangled soundscapes that holy hip hop assembled, from gangsta rap to urban gospel to dancehall, epitomized the tension between the leakiness of these sound worlds and the acute spatial distinctions and segregations that constitute the physical and social geography of Los Angeles. ${ }^{70}$ While the city is often read by urban planners, visual artists, and creative writers who offer optic experiences of urban life, I underscore its acoustic legibility. Call to mind the many misrecognitions of gospel rappers as "gangsters" in their cars in which the visual fails. The conceptual stakes of sound matter. The audible city has something unique to say.

\section{CHAPTER BREAKDOWN}

The musical stories relayed herein tell us what holy hip hoppers say and do in the name of the Jesus and in allegiance to hip hop music. The diversity of holy hip hop subjects, spaces, and sounds is only partially captured here, and yet black religious heterogeneity is one of the major ideas at stake in this book. When possible, I emphasize how black diasporic religious sensibilities circulate and infuse one another through hip hop performances in Los Angeles. Readers should not expect a linear history of holy hip hop or a full-fledged portrait of L.A.-based gospel rap. Instead, this is an ethnography of holy hip hoppers' transformative soundings and practices of conversion that produced specific musical, spatial, and spiritual possibilities and pathways through the City of Angels. Rather than arguing for the valorization of holy hip hop and gospel rappers, I am interested in how holy hip hop expressions sound out injustices and inequalities within black musical communities, segregations, and integrations across urban geography, and new social and spiritual imaginaries.

Chapter 1, “Now I Bang for Christ': Rites/Rights of Passage”, focuses on the making of holy hip hoppers through an amalgamation of stories about saving Los Angeles. I foreground the conversion narratives of holy hip hop artists as they intersect with certain discursive formations shaping and policing the geopolitical and social landscapes of the Southland in the 1980s and '9os. Discourses of urban reform and regeneration during these years were spiritually charged and linked to imaginations of disaster and apocalypse in the wake of major earthquakes and floods as well as the 1992 riots. The ideologies and mythologies at work in these 
tales of urban anxiety reveal the relationships between discourses regarding the "saving" of black youth from gang life, rescuing hip hop from its increasing profanity and commercialism, and rehabilitating and incarcerating criminals. For certain self-proclaimed gangbangers-turned-churchgoers, "bangin" was a way to represent their faith through music and fervently enact their loyalty to Christ. Hence, the common gospel rap turn of phrase emerging from the turning point of conversion: "Now I Bang for Christ."

Chapter 2, "Hip Hop Church L.A.: Shifting Grounds in Inglewood," chronicles the trials and triumphs of the Hip Hop Church L.A. in Inglewood-a monthly Friday night hip hop ministry started in 2007 by local activist-pastor Carol Scott and hip hop star-turned-pastor Kurtis Blow. Housed within the Holy Trinity Evangelical Lutheran Church, the hip hop ministry became a deeply contested terrain for members of the clergy and congregation. Conflicts over who was allowed entry into the realms of power and authority within this predominantly black church were often forged through ideological struggles over what constituted appropriate music and language in the pulpit. I situate gospel rap performances, sermons, and social interactions within the hip hop ministry in relation to the changing demographics and politics of Inglewood as a "fallen" city of African American upward mobility.

Building upon theories from critical human geography, chapter 3, "Beyond Babylon: Geographies of Conversion," explores how holy hip hoppers made use of urban spaces in unconventional ways, creating lively and experimental zones of social and musical contact. These zones were characterized by a surprising heterogeneity and intersectionality where multiple religious sensibilities mingled, sometimes coexisting, sometimes colliding, sometimes converting both people and places. While the social and territorial instability of Los Angeles has historically been managed and manipulated by state bureaucracies to implement specific agendas of urban reform, this same instability provided the conditions of possibility for city dwellers to radically re-vision and remake the existing urban milieu. Whether converting a Skid Row street corner into an "airborne church" or transforming the burned-out carcass of a gun store into a holy hip hop club, gospel rap artists animated "off the map" levels of urban history and experience.

Chapter 4, "The Evangelical Hustle: Selling Music, Saving Souls," examines how gospel rappers enacted what I term the evangelical hustle-that is, the daily moves they made to manage money, morality, and musical creativity through the twin pursuits of missionizing and marketing as well as how they "got their hustle on" for Christ instead of cash. The everyday flows and monetary exchanges involved in gospel hip hop performances and street evangelism-from the allocation of "formal" church offerings, to informal "love offerings" given to artists, to gospel rappers' repeated denials of payment for their CDs and musical services, to spontaneous gestures of generosity and resource sharing-complicated purely 


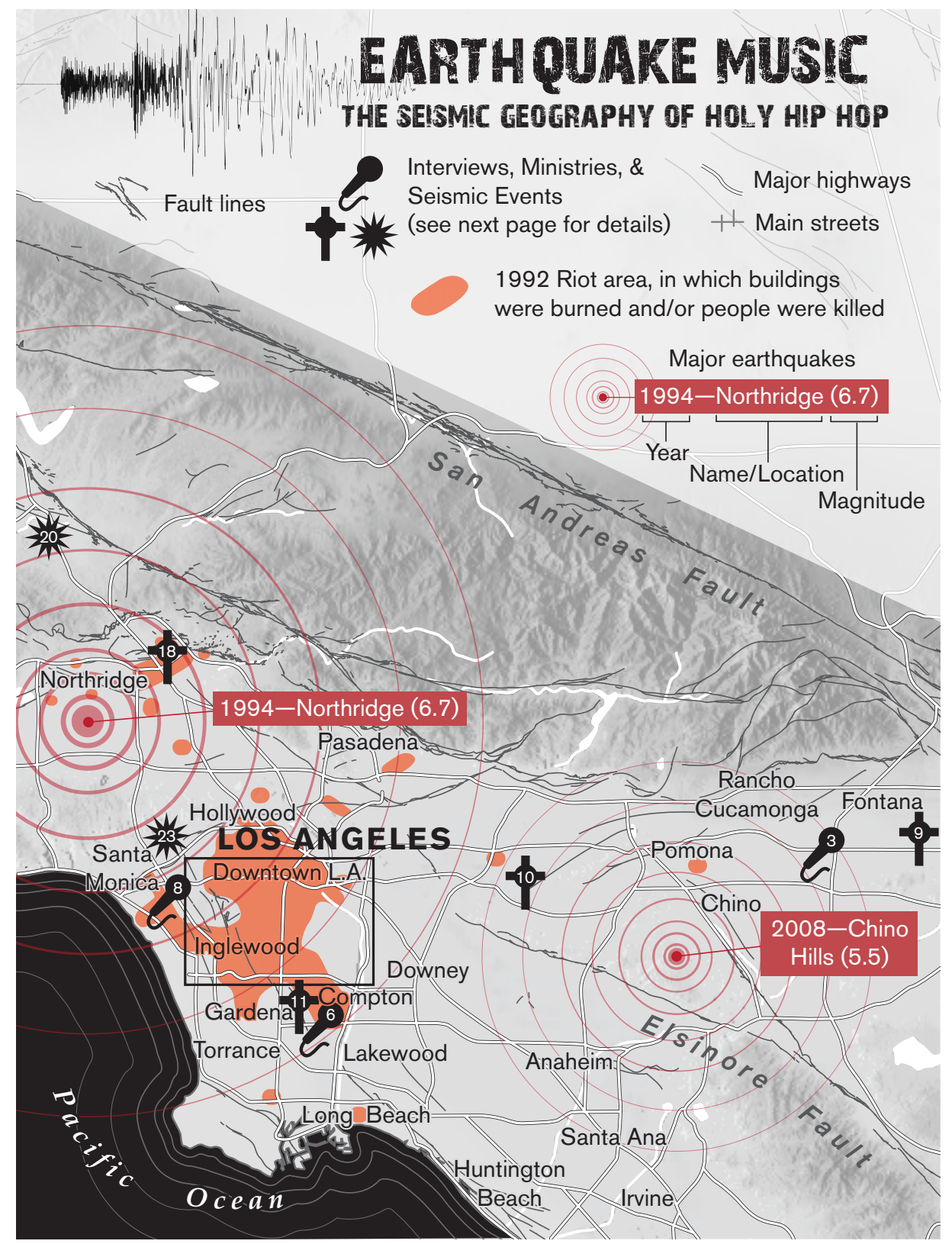

MAP 1. "Earthquake Music" map by M. Roy Cartography (refer to page 26 for map legend). 


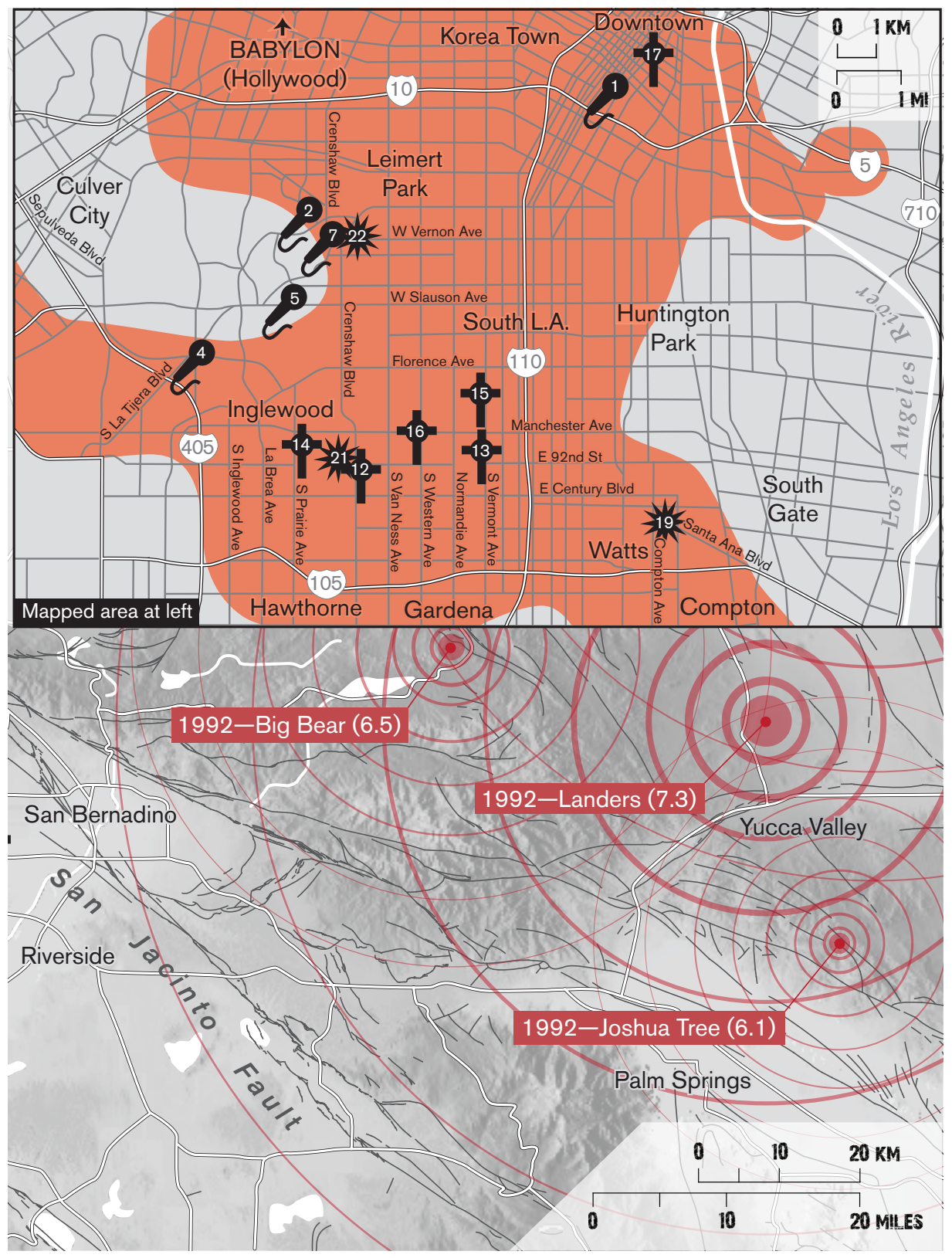

MAP 2. "Earthquake Music" map by M. Roy Cartography (refer to page 26 for map legend). 


\section{INTERVIEW LOCATIONS (selected)}

1 INTER

NTERNATIONAL FOOD COURT-2007 interview with Pastor Graham (hip hop pastor \& gospel rapper) in downtown Los Angeles during which he called holy hip hop "earthquake music"

2 FATBURGER AT BALDWIN HILLS CRENSHAW PLAZA-2007 interview with Khanchuz (gospel rapper); first post-war retail complex in California

3 FATBURGER IN RANCHO CUCAMONGA-2007 meeting with Soup the Chemist (gospel rapper) in the suburban city located in San Bernardino County

4 PANN'S RESTAURANT-Interview with Cue Jn-Marie (gospel rapper, pastor \& activist) at the 1950s coffee shop and diner; location of the famed Samuel L. Jackson scene from Pulp Fiction

5 WESTSIDE BIBLE CHURCH-First meeting and interview with Celah (gospel rapper from Hip Hopposite) and Slack (gospel rapper from IDOL King); now renamed Community of Faith Bible Church

6 SOUND DOCTRINE'S HOME STUDIO-Location of group interview with members of the gospel hip hop collective, Hip Hopposite: DJ Heat, Celah, B-Love, Sound Doctrine, and Crossfire; holy hip hop artists often gathered at the Compton home for bible study and to record tracks

7 FIFTH STREET DICK'S COFFEE AND JAZZ EMPORIUM-2008 interview with Majesty (gospel rapper) at the Leimert Park jazz hotspot founded by a former homeless man, Richard Fulton, right before the 1992 riots

8

IHOP-2008 meeting with Holy D (gospel rapper) at the well-known diner chain

\section{MINISTRIES \& CHURCHES}

10

LOVELAND CHURCH-Gospel rapper Soup the Chemist first performed holy hip hop at this Fontana church in 1986

VICTORY OUTREACH-Soup the Chemist and his group Soldiers for Christ (SFC) performed holy hip hop at numerous Victory Outreach churches throughout San Bernardino County in the late 1980s and early 90s GREATER BETHANY COMMUNITY CHURCH-Gardena church where B-Love (gospel rapper) got "saved" in the late 1990s and where Bishop Jones - brother to Jamaican singer, model, and actress, Grace Jones - is the pastor; now renamed City of Refuge Church PP CHURCH L.A. @ HOLY TRINITY EVANGELICAL LUTHERAN CHURCH-Initial Inglewood home to the Hip Hop Church L.A.; started in 2006 by rap legend-turned-minister Kurtis "Blow" Walker, Pastor Carol Scott, Sharon Collins-Heads, and Mike Green; now housed at Inglewood's Faith Lutheran Church

43 HIP HOP CHURCH L.A. @ TOTAL RESTORATION MINISTRIES-Hip Hop Church L.A. mobile ministry event on March 7, 2008 at a storefront church where Pastor Graham rapped and delivered a sermon

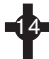
FAITHFUL CENTRAL BIBLE CHURCH @ THE FORUM-Famous Inglewood indoor arena and home to "The Takeover" Youth Ministry, a hip hop-inspired service established in 2005 and formerly pastored by newjack gospel icon, Kirk Franklin

15 CRENSHAW CHRISTIAN CENTER-Home to Pastor Fred Price, Jr.'s "Hip Hop Sunday" service during the early 2000s; the first event drew nearly 10,000 to the megachurch structure known as the Faithdome

$-16$ CLUB JUDAH @ LOVE \& FAITH CHRISTIAN CENTER-Weekly Saturday night hip hop praise party that began in 2003; hosted in a church building that was formerly a Western Surplus gun store

THE ROW (THE "CHURCH WITHOUT WALLS")-An "airborne" church that pastor/rapper Cue Jn-Marie leads every Friday night on the corner of Wall Street and Winston Street on L.A.'s Skid Row

FREEDOM FELLOWSHIP CHURCH-“Youth and Young Adult Hip Hop \& Rock Church" in San Fernando and home to Klub 20/Twenty - a Christian open-mic party where Khanchuz and other gospel rappers perform

\section{SEISMIC EVENTS}

WATTS TOWERS-At the height of gang-related violence in the late 1980s, 75 holy hip hoppers gathered in front of the towers with their bibles

-20 SIX FLAGS MAGIC MOUNTAIN-During the 1995 Holy Hip Hop tour, L.A. gospel hip hop groups Soldiers For

1 Christ, I.D.O.L. King, and the Gospel Gangstaz performed for hundreds of fans who climbed atop the stage, causing it to collapse

2 -21KDAR DARBY PARK - In 2004, Hip Hop Church L.A. pastor, Carol Scott, led a mock funeral procession with several hearses to the Inglewood park where people buried guns in a coffin to mourn victims of gang violence

22. KLUB ZYON @ KAOS NETWORK-A gospel hip hop open-mic founded by Cue Jn-Marie in 2006 and housed at a cultural center in Leimert Park; home to the well-known weekly underground hip hop event, Project Blowed

23- SCHOENBERG MUSIC BUILDING, UCLA CAMPUS-Gospel rappers B-Love and Khanchuz had performed for my "Cultural History of Rap" class at the UCLA Herb Albert School of Music when the 2008 Chino Hills earthquake struck (5.5M)

MAP 3. "Earthquake Music” map by M. Roy Cartography. 
economic notions of success and visibility. In this unique spiritual economy, gospel rappers transposed words and actions from the realm of gangbanging to street evangelism.

In the final chapter, I return to the broader themes of conversion and black liberation through an exploration of the multiple "Roads to Zion" that crosscut gospel hip hop. I link polyvalent renderings of Zion in L.A.-based holy hip hop to the spiritual traversals and tracks of rap stars such as MC Hammer, Nas, Snoop Dogg, Lecrae, and Kendrick Lamar. These intersecting quests for Zion through Christian, Muslim, and Rastafarian spiritual and musical sensibilities are creating new mappings of black diasporic religiosity. They point to new questions in the study of American popular music and religion that go beyond the categories of oppression and resistance, the religious and the secular. Further, they unveil how conversion-as a transformative practice in the lives of hip hoppers of various religious affiliations-is but one way to sound out life's path through the terrors and triumphs in the City of Angels, in America, and beyond. 